\title{
Die Heilige Gees en spiritualiteit in
}

\section{teologiese opleiding1}

\author{
Prof J H Koekemoer \\ Departement Dogmatiek en Christelike Etiek (Afd A) \\ Universiteit van Pretoria
}

\begin{abstract}
The Holy Spirit and spirituality in theological training

This arficle discusses the theme "spiritualiy" in ferms of changing paradigms.

The author argues that the present-day holistic perspective of spirituality can be regarded as a plenomenon of postmodernity. Aspects of this paradigm are: the emplasis on the relationship between the work of Cod's Spirit and human beings' encounter with God, as well as the relationship between human beings and God's creation. This indicates a holistic perspective on reality. The author discusses the question regarding spirituality in the context of the theological training of ninisters of the Nederdwitsch Hervornde Kerk. The shifl from modernity to postmodernity demands a rethinking of theological training. In theological training there should also be time for meditation. Theologians who want to speak about God should make time to listen of God.
\end{abstract}

\section{INLEIDING}

Daar kan verskillende redes aangevoer word waarom hierdie onderwerp 'n nadere omskrywing vra. Binne die geledere van die Nederduitsch Hervormde Kerk het Buitendag (1985) reeds in sy proefskrif melding gemaak van drie epogmakende wendinge in die mens se werklikheidsverstaan. Hy wys daarop dat voor hierdie wendinge die mens 'n mitiese mens was wat die wêreld alleen van binne geken het. Die Kopernikaanse wending het nie alleen die son na die middelpunt van alles verplaas nie, maar ook onder andere die ewolusieteorie tot gevolg gehad. Hierdie teorie word beskryf as 'n empiriese teorie wat die korrelaat van die vorm in die funksie van die lewende wese gesien het (kyk Darwin 1986:216-223). Uiteindelik het dit gelei tot 'n kousale werklikheidsverstaan van oorsaak en gevolg. Die derde wending, sê Buiten-

\footnotetext{
1 Voordrag gelewer by geleentheid van die opening van die Fakulteit Teologie (Afd A), Universiteit van Pretoria, op 25 Januarie 1999. Hierdie voordrag het ook gedien as besprekingsdokument by geleentheid van die VTT-kursus (Voortgesette Teologiese Toerusting) van predikante van die Nederduitsch Hervormde Kerk op die kampus van die Universiteit van Pretoria, Junie en November 1999.
} 
dag (1997:7), het gekom met die ontdekking van die mens se ek-bewussyn. Hy identifiseer vervolgens drie aksente wat hierdie wending teweeg gebring het.

- Die era van die termo-dinamika

- Albert Einstein se besondere en algemene relatiwiteitsteorie

- Die Kopenhaagse interpretasie van die kwantumteorie in die fisika.

Hans Küng (1990:3) is van mening dat ook die geskiedenis in terme van die wendinge geïnterpreteer moet word. Daarom plaas hy die draaipunt gedurende 1918 met die Eerste wêreldoorlog: 'The time of the shift from 'modernity' to 'post-modernity' is usually put too late, making it a 'sudden development' the tendency is to make the postmodern period begin in the 1970 s or 1980 s. But the basic onset of modernity already began with the collapse of the bourgeois society and Eurocentric world around the time of the first world war."

Hierdie wending word dan deur Buitendag beskryf as 'n wending vanaf 'n statiese na 'n dinamiese werklikheidsverstaan. Niks is nie, maar alles word. In terme van die teologie vra dit 'n grondige deurdenking van die dogmatiese leerstukke en hulle betekenis vir die huidige dag. 'n Formulering vanuit die pneumatologie kan dalk hier van betekenis wees. 'n Anekdote oor Karl Barth wil dit hê dat hy eenmaal gesê het dat hy graag die Kirchliche Dogmatik sou wou herskryf, die keer vanuit die perspektief van die pneumatologie. Dit sou daarom die moeite loon om weer na Buitendag se proefskrif te kyk en dan sy voorstel vir 'n teologie van die natuur binne hierdie verstaanshorison ernstig op te neem.

Terwyl Buitendag vanuit 'n post-moderne werklikheidsverstaan die teologiese werklikheidsverstaan uit die verlede krities interpreteer om tot nuwe teologiese sinsamehange te kom wei kollega A van de Beek (1996a) 'n hele boek aan 'n nuwe verstaan van die skeppingsleer. "Men zweer het geloof af met behoud van de klassieke theologie van die schepping, of men behoud het geloof, maar dan is een andere theologie nodig" (Van de Beek 1996a:16).

Hierdie teologie sal daarmee rekening moet hou dat 'n beperking van byvoorbeeld die begrip "skepping" tot die ontstaan in die begin, 'n soort skeppingsteorie na vore roep wat al weer iets anders as 'n belydenis is. In so 'n skeppingsleer gaan dit dikwels meer om verklaring as om belydenis. So word die skeppingsleer dan 'n teorie langs enige ander wetenskaplike teorie. As ons die verwoording van geloof 
egter sien as ' $n$ vorm van belydenis, dan gaan dit in die eerste plek oor God met wie ons in relasie is en van wie ons bely dat God reeds in die begin daar was. Dan kan ons God se handelinge nou en toe nie so kunsmatig van mekaar losmaak nie. Dit is een en dieselfde God in relasie tot een en dieselfde wêreld (Van de Beek 1996a:541). 'n Skeppingsleer wat sigself beperk tot die begin is in der waarheid geen skeppingsleer nie, maar 'n stuk natuurkunde of 'n stuk geskiedenis. Daarom bied Van de Beek 'n skeppingsleer waarin die totale werklikheid in relasie met God aan die orde kom (Van de Beek 1996a:9-10). Dit is denke in dieselfde rigting as Buitendag (1997:2). "Boonop het skepping ook nie net met die verlede te doen nie maar ook met die toekoms".

In dié geval maak die voorstel van Buitendag sin dat so 'n skeppingsleer onder die pneumatologie tereg sal kom. In die teologiese kurrikulum van die Fakulteit Teologie (Afd A) aan die Universiteit van Pretoria het ons juis dit probeer akkommodeer wanneer ons die sillabustema "werklikheidsverstaan" in die finale jaar onder die pneumatologie aan die orde stel. Dit is 'n geringe, tog ernstige poging tot die wegbeweeg van 'n fragmentasiebenadering in die teologie, na 'n meer geheelbenadering. Omdat 'n skeppingsleer spreke oor die wêreld in relasie met God is, sal die Christelike teologie oor God praat, deur ook spreke oor Christus in te sluit. In hierdie verband betoog Otto Weber dat pneumatologie, Christologie veronderstel (Weber 1981: 229). Dit is derhalwe interessant dat Van de Beek (1996a:155vv) naas ander sake 'n hoofstuk in sy boek wei aan die tema "Christologie en schepping". Juis daarom vra die benadering tot die skepping ' $n$ herbesinning van die totale teologiese kurrikulum.

In hierdie verband bring Buitendag (1997:1-77) in sy klasaantekeninge 'n holistiese benadering tot die saak na vore. Hy onderskei skerp 'n post-moderne werklikheidsverstaan van 'n moderne werklikheidsverstaan. Hy onderskei verskillende modelle, wek ' $n$ blik op die verlede en toekoms en begin wandel op die pad na 'n soeke van 'n teologie van die natuur. Vir hom is die fundamentele vraag die verhouding tussen God en die resultaat van God se skeppingsdaad, naamlik die kreatuur. 'Die gelowige kyk met 'ander ö̈' na die werklikheid, en 'sien' meer as die ongelowige raak - maar die vraag bly, en dit is die kruks, hoe geskied hierdie verbinding? Deur die vrae so te formuleer, plaas ons die aksent dan ook op die geskape skepping en nie slegs op die aktiewe skepping nie" (Buitendag 1997:65). Hierby kan die argumente van Peters (1992) en Cauthen (1986) wat in hierdie idioom dogmatiek bedryf, met vrug verreken word. 
Hierdie beweging van moderniteit na post-moderniteit het beide in die kerklike lewe en in 'n teologiese fakulteit waar predikante gevorm word, die vraag na spiritualiteit na vore geroep. Wanneer egter gevra word na die aard van spiritualiteit, tree 'n verskeidenheid antwoorde na vore. Uit die antwoorde lei 'n mens af dat dit iets te doen het met die meer emosionele kant van menswees. Suiwer gevoelsmatig is dit ook weer nie. Dit het met liturgie te doen, maar 'n liturgiese byeenkoms blyk nie die oplossing te wees nie (Van de Beek 1996a:3).

In die kringe van die Nederduitsch Hervormde Kerk is dit met etos in verband gebring (Buitendag 1992; Koekemoer 1995; Dreyer 1998). Etos is aan die ander kant net so moeilik beskryfbaar. Ons het hier nie met 'n voor die hand liggende saak te doen nie. Daar word tevergeefse pogings aangewend om dit in boeke terug te vind. Veral in "Hervormde teologie" is daar 'n terughoudendheid om hieroor te praat. 'n Teologie wat hoofsaaklik gekenmerk word deur ontdekkende nederigheid, praat moeilik oor sigself. Hou verder gedagte dat dit hier eerder om 'n lewenswyse as om logiese konstruksies gaan - en die huiwering om dit onder woorde te bring, word verstaanbaar.

Vir die aard van ons argument en in die lig van die argument sover lyk dit of spiritualiteit iets met die Heilige Gees te doen het. Volgens Van de Beek (1996b:4) beteken lewe in Christus immers tegelyk ' $n$ lewe in die Gees. "Zo gezien is de vraag na spiritualiteit een zeer terechte vraag. Het is de vraag naar ervaring van die Geest. Het is die vraag om althans iets daarvan te merken in de studie en bij de opleiding" (Van de Beek 1996b:4). Hiermee het ons egter nog nie deurgedring na die wese van spiritualiteit nie. Laat ons derhalwe in 'n poging om dit nader te omskryf, kyk wat andere daaroor te sê het.

In 'n artikel stel Dirkie Smit die vraag aan die orde of spiritualiteit werklik omskryf kan word (Smit 1989:83). Hy verwys na twee fasette van spiritualiteit wat, hoewel dit mekaar nie uitsluit nie, tog ook nie identies is nie. Die een is ekumeniese spiritualiteit en die ander gereformeerde spiritualiteit. Hy oordeel dat ekumeniese spiritualiteit nie 'n plaasvervanger vir "eie spiritualiteit" is nie. Ekumeniese spiritualiteit impliseer alleen dat die volle hoogte en diepte van die liefde van Christus slegs saam met al die heiliges ondervind kan word.

"Ekumeniese spiritualiteit" is dié ingesteldheid wat Schlink (1983) beskryf het as ' $n$ Kopernikaanse omwenteling, te wete die oortuiging dat die ander tradisies nie in bane, nader of verder, om 'n mens se eie tradisie wentel nie, maar dat almal saam 
rondom Christus as middelpunt wentel, en dat gevolglik nie gesoek moet word na onderlinge verskille ten einde dit oor en oor te bestending nie, maar dat veeleer gesoek moet word na die gemeenskaplike middelpunt: Jesus Christus (Smit 1989:84). Daarom oordeel Wainwright (1986:540-546) dan ook dat ekumeniese spiritualiteit 'n spiritualiteit van ontmoeting is. Hiermee is egter nog nie alles gesê oor of gereformeerde of hervormde spiritualiteit nie. As eie spiritualiteit bo en behalwe die gemeenskaplike, ook iets van die eie moet weergee, sal daar 'n poging aangewend moet word om die eie nader te omskryf.

Om juis dit te probeer doen bepaal Smit (1988:182) hom eers by wat hy noem die beskrywing van 'n metodologie ten opsigte van spiritualiteit. Vir die aard van hierdie voordrag gaan dit egter nie soseer om 'n metodologie as om die vraag na die "eie spiritualiteit" self nie. Hier kom 'n mens agter dat selfs gewone omskrywings nie voldoende is nie. Dit is wel in 'n sekere sin dit wat Ruhbach (1977:15) vormgewing van geloof in die alledaagse lewe noem. Dit is ook wel dit wat Wainwright (1986:59) as kombinasie van gebed en lewe beskryf, en wat Wakefield (1983) die manier waarop gebed 'n invloed om 'n mens se houding, gedrag en lewenstyl uitoefen, noem (Smit 1989:85). Op voetspoor van Graafland tipeer Jonker (1992:171) gereformeerde spiritualiteit as ' $n$ innerlike heilservaring van die hart in ontmoeting met God, 'n wyse van lewe van die gereformeerde mens. Dit is 'n lewe uit die erfgoed van die Reformasie, soos dit bepaal word deur die sola Scriptura, sola gratia en sola fide. Dit is ' $n$ lewe uit die Skrif soos dit verstaan is in die gereformeerde tradisie van die Reformasie en die Nadere Reformasie. Tereg sê Smit (1988:183) derhalwe dat die gereformeerde vroomheid opgebou is rondom die erediens en die huisgodsdiens. Die twee kernaspekte rondom die gereformeerde vroomheid is met ander woorde die gemeentelike godsdiensoefening en gemeentelike lewe daar rondom en die huisgesin wat ook individuele vroomheid en gemeenskapslewe insluit. 'n Mens sou ook kon sê dit gaan om nederigheid, afhanklikheid en gehoorsaamheid. Dit alles sal daarop gerig wees om die eer van God te dien.

Smit (1988:188) wys daarop dat hierdie klem op gehoorsaamheid en die eer wat aan God verskuldig is, tot op die punt van burgerlike ongehoorsaamheid in die Calvinistiese tradisie soos ' $n$ refrein in verskillende situasies deurbreek. Die vraag wat vir ons van betekenis is, is of Hervormde vroomheid so getipeer kan word. Veral as Buitendag (1992:1) se tipering dat spiritualiteit ook gevorm word in die bedding van 'n geloofsgemeenskap en so 'n bydrae vorm tot identiteitsvorming. Dit het met 
ander woorde te make met die eie unieke aard van 'n bepaalde geloofsgemeenskap. Die vraag is: Wat is die eie unieke aard van die Hervormde Kerk wat ook al weer verskil van die gereformeerde spiritualiteit soos hierbo beskryf?

Denkers binne die Hervormde Kerk wys op bepaalde aspekte wat hierin 'n rol kan speel. Pont (1994:106-107) en Oberholzer (1992:578-579) wys op die betekenis van Hoedemaker. Buitendag (1992:3) wys op die invloed van die dialektiese teologie van Karl Barth asook die eksistensiedenke van Bultmann. Koekemoer (1995:877) wil op. voetspoor van Haitjema praat van 'n eksistensieel-teologiese en dialekties-paradoksale benadering. Loader (1987:48) beklemtoon die invloed van die Etiese Teologie. Hierdie agtergrondskets dui daarop dat Hervormde spiritualiteit moeilik definieerbaar is en moeilik onder een noemer gebring kan word. Hier is sprake van 'n ontdekkende nederigheid waar dit moeilik is om oor jouself te praat. Die ontdekkende nederigheid waarvan hier sprake is, tree juis na vore uit 'n innerlike oortuiging dat geen leerstuk, dogma of sisteem die volle waarheid oor God kan omvat nie. Tog praat ons ook in leerstukke, dogmas en sisteme. Om so te praat is derhalwe nie sinloos nie; maar daar moet 'n erkenning wees dat hierdie alhoewel eerbaar, tog feilbare menslike pogings is om die onsêbare te sê. Kerklike leer is nooit onbelangrik nie, maar dit word geplaas binne 'n ontmoetingsgebeure met God, as die kerklike verwoording van die ontmoeting ten dienste van 'n nuwe ontmoeting (vgl Berkhof 1973:32; Ott 1974:79).

Die verandering van die samelewing wat in die. Calvinistiese tradisie so 'n deurslaggewende rol gespeel het (Smit 1988:190), tree nie binne die Hervormde tradisie met dieselfde intensiteit na vore nie. Het dit dalk iets te doen met wat genoem word die ontdekkende nederigheid in ons teologiebeoefening? Geloof is binne Hervormde tradisie immers altyd gesien as 'n gawe wat nie herlei of beplan kan word nie. Op 'n eksistensiële wyse word hier onder woorde gebring wat Schleiermacher in sy vroeg negentiende-eeuse taalveld 'n absolute afhanklikheidsgevoel genoem het. Dit is hier waar gelowiges uit verskillende tradisies mekaar kan ontmoet. Hier kan ons en Paulus, in geselskap van Augustinus saam met Luther asook die swaar gereformeerdes met ' $n$ gesprek begin. Dit is by hierdie besef van absolute afhanklikheid, die laaste afhanklikheid, wat aan niks meer gehak kan word nie, waar die gesprek begin. Hierdie is nie 'n afhanklikheid van iets of iemand in die wêreld nie, dit is ' $n$ laaste afhanklikheid. Dit is hier waar die onsêbare, onnoembare, onbevatlike ervaar word as die Ander. Dit is juis hierdie Ander wat ons aanspreek, oprig en troos. 
Dit is die Persoon wat alle ander persone te bowe gaan. Dit is die Prsoon wat ons op dié Persoon se eie wyse ontmoet (Van die Beek 1987:115). Dit is ook hier waar in 'n gesprek oor spiritualiteit daar oor die Heilige Gees gepraat moet word. In die taal van Van de Beek (1987:17) wil ek in my eie woorde sê:

Die Heilige Gees is die Goddelike aanwesigheid wat ons aanspreek. Dit is die roepstem van God wat tot ons kom. Daarom word die Heilige Gees deur ons ook as God bely. As Jesus as God se verskyning nie meer by sy dissipels is nie, kom die Heilige Gees om hulle te vertroos. Die Heilige Gees is nou die Goddelike teenwoordigheid wat ons lewens van die sinloosheid bevry en in wie ons die ewige lewe ontvang. Die Gees is God se aanwesigheid en daarom nie herleibaar nie. Ons ervaar God se werk in ons lewens, maar God self bly "verborge geheimenis".

Wie die Heilige Gees wil vasgryp, staan met leë hande. Want die Gees is pneuma en pneuma beteken wind. Wie die wind wil gryp het niks gegryp nie. En hoe harder jy gryp, hoe minder het jy. Wie die Gees wil vasgryp het niks gegryp nie. Hy het ook van die Gees niks begryp nie. Want die Gees is die onbevatlike aanwesigheid van God.

Ons behoort 'n uitspraak van Van de Beek (1987:523) ernstig te neem as hy sê dat vanweë die ontmoetingskarakter van geloof dit wesenlik belangrik is om oor die Gees te praat. Ook wanneer ons oor spiritualiteit binne die teologiese opleiding praat. Die Gees is immers die Ander een wat ons aanspreek en nie bloot iets anders wat een of ander effek op ons lewens uitoefen nie. Dit is God wat ons aanraak, daarom word ons nuwe mense. Ons lewe nie slegs in die heil van God omdat Jesus Homself tot in die dood vir ons gegee het nie, maar ook omdat God ons in ons eie tyd as die heilvolle God ontmoet.

Die vraag van Luther, Hoe en waar ontmoet ek 'n genadige God?, hou ons steeds besig. Daar is ' $n$ antwoord wat lui: nie deur kerkgang, of deur die doop, of deur lid te word van 'n bepaalde instituut nie, maar alleen deur 'n persoonlike keuse van die hart. Binne ons eie geledere het ons nogal meermale afstand probeer kry van so 'n antwoord. By ons het die verbond so 'n belangrike rol gespeel dat dit nie gerelativeer is deur die noodsaak van persoonlike bekering nie. Ons is bang vir die klompie "ware" Christene binne die breëre gemeenskap van die verbond. Daarvoor het die volkskerkgedagte by ons dalk 'n te oorheersende rol gespeel. Die persoonlike betrok- 
kenheid van lede is dikwels opgeoffer binne die verbondsbeskouing van die volkskerkgedagte. Hierdie eensydigheid het ongelukkig ook veroorsaak dat die volk dikwels belangriker as geloof geword het. Die denke vanuit die kollektiewe het 'n manier om die teologiese gesprek te laat ontspoor wanneer versigtigheid agterweë gelaat word. Wie begin by die kollektiewe waarin die Gees werk, vergeet dikwels te maklik dat die Gees God se teenwoordigheid in hierdie wêreld is. Laat ons in gedagte hou dat die Gees sowel in die enkeling as in die gemeente werk. Dit sou onjuis wees om die een teen die ander af te speel. Beide loop parallel. Die Gees tree die lewe van individuele mense binne. Tegelyk woon die Gees in die liggaam wat die gemeente is en raak van daaruit die lewe van mense aan (Van de Beek 1987:57).

Dit wil voorkom of die gereformeerde tradisie neig na die primaat van die enkeling. So sê die Nederlandse Geloofsbelydenis immers in Artikel 28 dat elkeen hom of haar by die ware kerk moet voeg. Ander tendense kan egter ook aangewys word. Die Heidelbergse Kategismus sien die kerk byvoorbeeld nie primêr in die enkele gelowige en selfs nie in die Christelike gemeenskap nie, maar in die volk van God van die begin van die wêreld af (Van de Beek 1987:59). Dit alles dui in die rigting dat ons by 'n teologiese kurrikulum baie genuanseerd behoort te dink. Eensydigheid, na watter kant toe ook al, het in die verlede en kan ook in die toekoms vir die kerk katastrofale gevolge hê.

Hierdie perspektief vanuit die pneumatologie gee aan spiritualiteit 'n bepaalde plek. 'n Ander vraag wat egter nog nie beantwoord is nie, is hoe kom dit wat gesê is in 'n teologiese opleiding van predikante aan die orde? In hierdie verband oordeel Van de Beek (1996b:4), dat dit 'n bepaalde wyse van opleiding behels. Omdat dit so is, sal daaraan nie voldoen kan word deur naas die studie net nog 'n byeenkoms te hê waarin meer aandag aan die affektiewe aspekte van teologiese opleiding gegee kan word nie. By die praktykvorming van studente via die Sentrum vir Teologiese Navorsing en Toerusting het ons nogal in hierdie rigting geneig. Ons sou by die skepping van die Hervormde Teologiese Kollege (wat beplan word om ineengeweef met die "nuwe" gealmageerde teologiese fakulteit aan die Universiteit van Pretoria vanaf 1 Januarie 2000 te funksioneer) moet waak daarteen om nie op dié pad te beweeg nie. Die akademiese en kerklike vorming kan nie so kunsmatig van mekaar geskei word nie. Dit gaan om 'n uitgangspunt eerder as kunsmatige byvoegings op bepaalde stadia van die opleiding. 
Karl Barth (1962) het na sy aftrede nog een keer 'n kursus aangebied wat in die boek: "Inleiding in die evangeliese teologie", op skrif gestel is. Daarin gaan dit oor die teoloog en oor die vraag na die lewenswyse van die teoloog. Studie, gebed, die Bybel, meditasie word onder andere geïdentifiseer as van lewensbelang. In hierdie verband merk ons steeds 'n soort leemte in ons eie teologiese opleiding. Daarom dalk die aandrang na meer spiritualiteit.

Studente beleef dikwels ons teologiese opleiding as gefragmenteerd. Oplossings wat aangebied word om 'n heelheid te vorm, slaag skynbaar nie. Die indruk bestaan soms dat hoe meer ons probeer om 'n eenheid tussen etos (spiritualiteit) en akademiese bedrywighede te bewerk, hoe groter word die gaping. Elke poging verword tot 'n tegniek wat nie in die doel slaag nie. Dalk is Van de Beek (1996b:6) reg as hy beweer dat dit deel van ons eie erfgoed is. Ons studente het kognitief kennis geneem van die klassieke geloofsgoed, maar hulle eie bestaan is ontwortel deur die tallose kritiese vrae wat hulle tydens hulle opleiding geleer het om te vra - goed toegerus om krities-wetenskaplik te werk, maar nie altyd in staat om dit binne die eie lewe te verdiskonteer nie. Ek pleit nie vir die uitskakeling van krities-wetenskaplike opleiding nie. Inteendeel, akademies-geskoolde teoloë kan nooit kritiekloos wees nie. Daar mag egter nooit by kritiese vrae stilgestaan word nie. Om deur te dring na lewensomvattende antwoorde sal 'n heroriëntasie ten opsigte van uitgangspunte in teologiese opleiding vra. Ons sal moet leer om die rykdom van die geloof vir ons gefragmenteerde en chaotiese samelewing oop te dek.

Hier sal tegnieke nie help om eksistensiële verleenthede op te los nie. Professionalisering van die predikant se werk is ook nie 'n oplossing nie. Dit help weinig as jy weet hoe om ' $n$ begrafnisdiens liturgies te orden as jy nie weet hoe om met die vrae van lewe en dood en die sinloosheid van menslike lyding om te gaan nie (Van de Beek 1996b:7). As jy weet hoe om met hierdie vrae om te gaan is die tegniek van minder belang. Tegnieke kan 'n handige hulpmiddel wees, maar dit kan nooit 'n spirituele leegheid vervang nie. 'n Heroriëntasie ten opsigte van teologiese opleiding vra dat die gefragmenteerdheid van die teologiese dissiplines in 'n geheelprogram van predikantevorming gerig op geloofskommunikasie in die eie tyd ingeklee moet word. Dit help ook nie om van predikante kommunikasiekundiges te maak deur hulle te leer om beter verkoopspraatjies oor hulle produk (die evangelie) te lewer nie. Wie nie self deur die produk vasgegryp is nie, verander gou in 'n smous. 
Die gevaar van 'n "verwetenskapliking" van die teologie kan opgevang word deur erns met spiritualiteitsvorming te maak. Teologiese opleiding moet daarteen waak om die totale aksent op die predikant se kennisfunksie en doen-funksie te plaas, terwyl die predikant se wees-funksie met die oog op die kweek van 'n egte Bybelse spiritualiteit en die vorming van 'n eie identiteit binne die tradisie, agterweë gelaat word.

(Dreyer 1997:23)

Terwyl ek dit sê, moet ek andermaal tegelyk sê dat die werk van die Heilige Gees ook weer nie afhanklik is van ons spiritualiteit nie. Die normale gang is dat die Gees met mense werk, maar dit is wat Van Ruler (kyk Van de Beek 1996b:7) noem geleende spiritualiteit. Predikante behoort nooit by die situasie te beland dat hulle nie in staat is om hierdie geleende spiritualiteit te kommunikeer nie. Dit gaan oor die kommunikasie van geloof - nie die verkoop van eie gevoelens nie. Tog moet onthou word dat geloof nie sonder eie geloof gekommunikeer kan word nie. Teoloë mag nie wegkruip in die ivoortoring van hulle wetenskaplikheid nie. Die aanvegtings en uitdagings van die lewe moet aangepak en in die lig van die evangelie deurworstel word.

In ons eie teologiese idioom bepaal die metode immers nie in die eerste plek die saak nie. Die inhoud van spreke bepaal of jy met teologie besig is of nie. Daarom kan teologie op akademiese vlak allermins beoefen word sonder dat die waarheidsvraag op een of ander wyse aan die orde kom. Sodra die kriterium van die waarheidsvraag uit die gesigsveld verdwyn, kom daar ander kriteria op die voorgrond; soos onder andere nuttigheid en/of relevansie. 'n Teologie wat só figureer, verraai 'n geloofsverbondenheid. Die gevaar wat hieruit voortspruit, is dat die Christelike geloof gedegradeer word tot 'n bloot maatskaplike saak.

Daarom is my pleidooi vir gebalanseerdheid en genuanseerdheid in teologiebeoefening so belangrik. Die teologie kan nimmer kritiekloos ortodoks of kritiekloos maatskappy betrokke wees nie. Om met Van de Beek (1996b:7) te praat: Geskoolde akademiese teoloë mag nooit nie kritiekloos wees nie. Maar hulle mag ewe min by kritiese vrae bly vassteek. Hulle moet funksioneel wees in hulle ganse lewe, ter wille van hulleself en van ander mense.

In die woorde van Oberholzer (1992:501) het dit nou haas tyd geword om my wandelinge te staak. Ook op die stadium bly die beeld in die spieël wat hierdie saak betref, nog onhelder. Maar eerlike selfondersoek, ook ten opsigte van die politieke en 


\section{Die Heilige Gees en spiritualiteit}

sosio-ekonomiese konteks wat ook in houdings en oortuigings 'n rol speel is belangrik. Omstandighede dwing ons om in ons gehoorsaam-heid aan God die ekumeniese aard van die kerk, ook in die opleiding van predikante, raak te sien. En aan 'n pastorale bewoënheid met die menslike nood van ons tyd sal ons nie kan ontkom as ons dit eerlik meen met die evangelie nie.

Ek laat my ten slotte graag leer deur my kollega in Leiden, prof A Van de Beek (1996b:10). Kerk en universiteit sal in die opleiding van predikante keuses moet maak. Om alles vir almal te wees is net nie meer moontlik nie. Die papier en administratiewe oorlog aan universiteite sal onder andere aangespreek moet word. Tensy die kerk oortuig is dat die kerk se teoloë en hoogleraars sonder spiritualiteit kan funksioneer, sal die verbrokkeling van tyd wat deur 'n oormaat administrasie veroorsaak word, aangespreek moet word. 'n Oormaat van vergaderings en ander pligte het tot gevolg dat mense nie tyd het om te lees, te hoor en te mediteer, te dink en vrae te vra en te deurdink nie. Daar is nie tyd vir bid en opbouende gesprek nie en studente word net masjiene wat punte versamel.

Ons sal moet leer dat kennis met verwondering begin en in verwondering eindig. Daarom begin geleerdheid dikwels by stilte en lei tot stilte. Teologie begin met swye en eindig met swye. Wie oor God wil praat moet na God se Woord kan luister, kan stil word en kan bid. Anders praat jy in jou poging om iets oor God te sê later net oor jouself en luister jy gevolglik net na jouself. 'n Kerklike teoløgiese opleiding sal derhalwe moet toespits op die teologie se eintlike taak: die ontwikkeling van die besinning oor die geloof en die vorming van predikante in die kerk wat juis dit ook aan ander mense kan oordra. My bede is dat beide die ekumeniese aard van teologiebeoefening en die eie aard van predikante-opleiding vir die Nederduitsch Hervormde Kerk binne die nuwe strukture van die teologiese fakulteit vanaf 2000 nie alleen gestalte sal kan kry nie, maar dat 'n daadwerklike bydrae gelewer kan word tot die geheelvorming van mense vir die bediening van die Woord van God.

\section{Literatuurverwysings}

Barth, K 1962. Einführung in die evangelische Theologie. Zürich: Ev2 Verlag..

Berkhof, H 1973. Christelijk Geloof. Derde druk. Nijkerk: G F Callenbach.

Buitendag, J 1985. Skepping en ekologie: 'n Sistematiese ondersoek na die teologiese verstaan van die werklikheid. DD-proefskrif, Universiteit van Pretoria. 
Buitendag, J 1997. Werklikheidsverstaan. Studiegids, Departement Dogamtiek en Christelike Etiek, Teologie (Afd A), Universiteit van Pretoria.

Canthen K 1986. Systematic Theology: A modern Protestant approach. New York: Edwin Mellen Press.

Dreyer, T F J 1998. Spiritualiteit, identiteit én die etos van die Nederduitsch Hervormde Kerk. HTS 54(1\&2), 289-314.

Jonker, W D 1992. Spiritualiteit en Godsverduistering. NGTT 32(2),170-178.

Koekemoer, J H 1995. Die etos van die Nederduitsch Hervormde Kerk. HTS 51, 876-880.

Küng, H 1988. Theology for the third millenium. London: Harper Collins.

Loader, J A 1987. Tertium datur - oor die etiese waarheidsbegrip. HTS 43, 47-57

Oberholzer, J P 1992. Terugblikke op die Fakulteit Teologie (Afd A). HTS 48, 575584.

- 1992. Fakulteit Teologie (Afd A) aan die Universiteit van Pretoria: Vrae oor sy identiteit en problematiek. HTS 48, 493-504.

Ott, H [1971] 1974. God. Richmond Virginia: John Knox Press.

Peters, T 1992. God-the world's future: Systematic Theology for a post-modern era. Minneapolis: Fortress.

Pont, A D 1994. Historiese perspektiewe op die kerklik-teologiese opleiding van die Nederduitsch Hervormde Kerk aan die Universiteit van Pretoria. HTS 50 (1\&2), 95-110.

Ruhbach, G 1977 s v. Theologie und Frömmigkeit. TRE 11, 674-683. Berlin: Töpelmann.

Schlink E 1983. Ökmenische Dogmatik. Göttingen: Vandenhoeck \& Ruprecht.

Smit, D J 1988. Wat is gereformeerde spiritualiteit. NGTT 29(2),182-193.

- 1989. Kan spiritualiteit beskryf word. NGTT 30(1), 83-93.

Van de Beek, A 1987. De adem van God. Nijkerk: G F Callenbach.

- 1996a. Schepping: De wêreld als voorspel voor de eeuwigheid. Baarn: G F Callenbach.

- 1996b. Spiritualiteit: Een must voor theologen? GTT 96(1), 3-10.

Wainwright, G 1987. Ecumenical Spirituality, in Jones, Wainwright \& Yarold (eds) 540-548.

Wakefield, G (ed) 1983. A dictionary of christian spirituality. London.

Weber, O 1961. Gründlagen der Dogmatik. Göttingen: Moers. 